\title{
Fronteiras em perspectiva: um debate sobre os limites territoriais do sul da Argentina no século XIX
}

\author{
Alessandra Gonzalez de Carvalho Seixlack ${ }^{1}$ \\ Ana Carollina Gutierrez Pompeu ${ }^{2}$
}

\begin{abstract}
Resumo: Garantir o monopólio do poder coercitivo por meio dos exércitos nacionais foi pré-requisito para o reconhecimento dos Estados-Nação durante o século XIX nos âmbitos internos e externos. Na Argentina, a profissionalização das forças militares permitiu a centralização política de Buenos Aires e a ocupação definitiva da Patagônia após conflitos vitoriosos com as sociedades indígenas. A expansão da chamada "fronteira interna", que marcava o limite entre a sociedade criolla e as indígenas, foi concomitante ao processo de definição dos limites internacionais, encerrando assim a consolidação do Estado argentino. No entanto, o aumento da capacidade do Estado em atuar em regiões afastadas como os desertos do sul esbarrou nas similares pretensões do Chile, que havia se afirmado no cenário internacional, após a experiência da Guerra do Pacífico, desencadeando uma corrida por tratados de limites.
\end{abstract}

Palavras-chave: Fronteira; Patagônia; Estado Nacional.

\section{Frontiers in perspective: a review about the territorial limits of south Argentina in the nineteenth century}

\begin{abstract}
The National state building in the XIXth century guaranteed the monopoly on coercive power in the internal and external scopes by the national armies. In Argentina the army forces' professionalization allowed Buenos Aires political centralization and the final occupation of Patagonia after victories against Indigenous people societies. The "internal frontier" expansion, which marked the limit between criolla and Indigenous people societies, was simultaneous with the process that defined the international boundaries and ended the consolidation of Argentinean state. Nonetheless, the increases of states' capacity for acting in remote zones as the south deserts crushed with similar intentions from Chile, that have been affirmed in the international scene after experiment Pacific War which caused a running for boundaries treaties.
\end{abstract}

Keywords: Frontier; Patagonia; National State.

\footnotetext{
${ }^{1}$ Doutora em História Social da Cultura pela Pontifícia Universidade Católica do Rio de Janeiro (PUC-Rio) e bolsista do CNPQ. E-mail: gonzalez.alessandra@gmail.com

${ }^{2}$ Doutoranda em História pela Universidade de Brasília (UNB) e bolsista do CNPQ. E-mail: anagpompeu@gmail.com
}

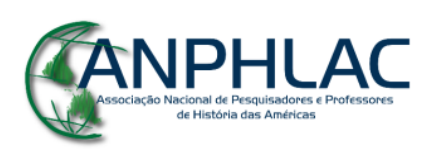

Revista Eletrônica da ANPHLAC, ISSN 1679-1061, №. 22, p. 86-117, Jan./Jun., 2017.

http://revista.anphlac.org.br 
Artigo recebido em: 31/10/2016

Artigo aprovado para publicação em: 16/02/2017

\section{Introdução}

O processo de formação dos Estados Nacionais na Argentina e no Chile foi acompanhado pelo conflito com as populações indígenas, em busca de suas definições de nacionalidade e de conformação territorial. As relações desses dois países com seus índios, sobretudo com os habitantes do Pampa e da Patagônia na Argentina e da Araucania no Chile, foram transformadas no momento de consolidação institucional desses Estados quando a alternativa da guerra foi adotada no sentido de acabar com séculos de resistência nativa e de impor o poder hegemônico do Estado moderno. (OSZLAK, 2009; BECHIS, 2010)

A destituição formal das "fronteiras internas" ou das "zonas de contato" entre as sociedades indígenas e hispano-americanas pelo Estado tinha em vista a ocupação das áreas de soberania indígena e a demarcação definitiva das fronteiras internacionais e dos territórios pertencentes a cada república. Nesse momento, iniciado na segunda metade da década de 1870, os processos de miscigenação, interação e negociação existentes nas zonas de contato foram ignorados e substituídos pela imposição de um modelo de sociedade no qual os grupos étnicos do sul do continente não se enquadravam.

\section{Sobre os limites internos}

Até as últimas décadas do século XIX, o sul das atuais províncias argentinas de Buenos Aires, San Luis, Córdoba, Santa Fé e Mendoza representavam o "limite" entre a “civilização e a barbárie”, conforme a terminologia empregada na época. Entre as áreas ocupadas pelos criollos e os locais habitados por diferentes sociedades indígenas, estava uma região denominada de "fronteira", uma vez que era considerada uma herança da colonização espanhola.

A partir da década de 1860, a terminologia mais utilizada para designar essa região de contato com as sociedades indígenas foi "fronteira interna", o que estabelecia um contraste com as fronteiras internacionais, além da implícita intencionalidade do Estado de eliminar sua existência. (BANDIERI, 2009, p. 66) A partir de então, deu-se

\section{GANPHLAC}

Revista Eletrônica da ANPHLAC, ISSN 1679-1061, №. 22, p. 86-117, Jan./Jun., 2017.

http://revista.anphlac.org.br 
início ao processo de territorialização das áreas indígenas, no sentido de integrá-las juridicamente ao Estado que se consolidava nesse período. (QUIJADA, 2011, p. 11)

El desierto quedó intacto, solo infestado por miles de salvajes que robaban, incendiaban, cautivaban, asesinaban a las poblaciones de las fronteras interiores, quedando la Republica mitad independiente y la otra mitad en poder de los bárbaros. (Julio Argentino Joca, mayo de 1914, Archivo General de la Nación, p. 1)

O trecho acima demonstra que o termo "fronteira interna" foi utilizado em um momento de mudança das estratégias do Estado sobre as populações indígenas, que promoveu ações militares na década de 1870 com o objetivo de incorporar as regiões do Pampa e da Patagônia definitivamente ao seu poderio. O deserto, como referido acima, era o conceito utilizado para definir os espaços sobre os quais o Estado não exercia domínio efetivo, assim como para desqualificar as populações indígenas ao imaginarem-nas como habitantes de um espaço vazio - um vazio, porém, que fazia alusão à população civilizada, conforme idealizado pelos intelectuais e políticos argentinos. (TORRE, 2010, p. 10) Para a elite política e intelectual do período, os espaços considerados "desertos" deveriam ser incorporados ao restante do país pela introdução da população considerada "civilizada", a única capaz de "povoar" esses territórios de acordo com os referenciais pretendidos, em oposição àquela considerada "bárbara":

\begin{abstract}
A medida que van poblándose sus vastos territorios desiertos, el valor de éstos se decupla, la producción aumenta en proporciones enormes, y esto en virtud de que una sola familia, con el auxilio de máquinas modernas, puede poner en explotación grandes extensiones de tierra, y obtener así un producto mucho mayor que el necesario para su propio consumo. (ALBERDI, 1852, p. 66)
\end{abstract}

De acordo com o trecho de Alberdi, a única povoação possível para os desertos era aquela que combatesse a dicotomia entre a "civilização e a barbárie", o que demonstrava as pretensões do Estado em dominar esse vasto território indígena com políticas de imigração, principalmente de países industrializados europeus. Tal pensamento era uma evidência da impossibilidade de sobrevivência das populações indígenas em longo prazo, uma vez que estas representavam a não atuação do poder estatal nesses espaços. Com o processo de consolidação do Estado nacional argentino nas últimas décadas do século XIX, a "fronteira interna" foi combatida para que o

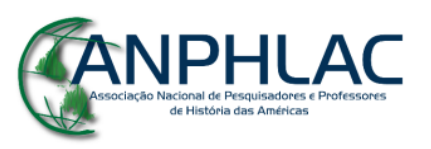

Revista Eletrônica da ANPHLAC, ISSN 1679-1061, №. 22, p. 86-117, Jan./Jun., 2017.

http://revista.anphlac.org.br 
Estado pudesse se afirmar sobre toda extensão do território que se apresentava como “Argentina”. (JONG, 2011, p. 81)

Apesar das situações de conflito e resistência e do próprio discurso da época, a fronteira não era um limite, mas uma zona de contato. (NACUZZI, 2010, p. 11; PRATT, 2008, p. 7) De acordo com Lídia Nacuzzi, as sociedades indígenas sofreram modificações em virtude da presença criolla desde o século XVII. A utilização de animais como o cavalo e o gado, além de outros bens de consumo, alterou a forma com que essas sociedades se relacionavam entre si e com os criollos. Ao introduzir o gado, que passou a existir livremente no Pampa após a chegada dos espanhóis, em sua alimentação e comércio, o indígena começou a competir com os criollos por esses animais, levando ao seu esgotamento e ao consequente conflito, já que esses animais passaram a ser aprendidos nas estâncias criollas.

Essa dinâmica de interações e a grande importância do gado acarretou em profundas modificações nas sociedades indígenas, alterando a lógica de riqueza perpetuada pelos caciques (líderes das organizações indígenas), já que os de maior importância eram aqueles que possuiam um maior número de animais. (MASSES, 2010, p. 23) Além da tensão existente entre indígenas e criollos, sobretudo pela disputa desses animais, o mundo da fronteira também era composto por miscigenações, comércio e interações pacíficas. No entanto, esse espaço foi muitas vezes descrito pela literatura do século XIX como um limite entre duas culturas antagônicas, mesmo que na prática caciques influentes fossem mestiços e transitassem entre as duas sociedades.

Muitas vezes nesse trabalho, adota-se a denominação genérica de "sociedades indígenas" para se referir aos habitantes das áreas não criollas por se tratar, em realidade, de diversas etnias mestiças (incluindo os muitos grupos étnicos que vieram do lado ocidental da Patagônia). Muitas das categorias étnicas utilizadas para designar esses grupos indígenas foram impostas pela sociedade hispano-criolla como uma forma de simplificar as interações e a localização dessas etnias. (NACUZZI, 1998, p. 243)

De uma forma geral, ranqueles, salineiros, chilenos, huilliches e pehuenches foram os que mais tiveram contato com a sociedade criolla (BECHIS, 2006, p. 7), sendo que os salineiros se localizavam no Pampa úmida, a oeste de Buenos Aires. Grande parte dos tehuelches habitava o norte da Patagônia argentina, correspondente à atual província de Neuquén; os ranqueles viviam nas proximidades da província de

\section{CANPHLAC}

Revista Eletrônica da ANPHLAC, ISSN 1679-1061, №. 22, p. 86-117, Jan./Jun., 2017.

http://revista.anphlac.org.br 
Córdoba; e ainda os grupos selk'nam, onas e yámanas habitavam a Terra do Fogo, na Patagônia austral. (QUIJADA, 2011, p. 85; BANDIERI, 2009, p. 37)

A forma como a Espanha expandiu seus domínios no período colonial também auxilia a compreender a questão territorial na Argentina do século XIX. A Coroa espanhola exerceu sua expansão sobre o continente americano levando em consideração as bulas papais e tratados como o de Tordesilhas. As terras americanas, mesmo que ainda não inteiramente conhecidas, faziam parte dos domínios do rei e os habitantes, a exemplo dos índios, eram seus súditos. (BANDIERI, 2009) Dessa forma, os territórios do Pampa e da Patagônia estavam incluídos nos domínios da República Argentina, pois eram considerados parte da administração desde o período colonial.

Por essa lógica, o governo central considerava que a expansão territorial não era realizada em território totalmente autônomo, mas em área de jurisdição argentina, muito embora se reconhecesse a presença e a dominação indígena. A disputa por terras ocorrida durante o processo de expansão da fronteira interna teria o objetivo de garantir a posse efetiva pelo governo criollo. Por sua vez, os povos originários da América consideravam sua ancestralidade um fator mais relevante que o raciocínio jurídico oriundo da colonização espanhola, o que resultou, no caso analisado, na resistência indígena em ceder à área ocupada.

Após a independência, e, sobretudo, após os conflitos entre Buenos Aires e as demais províncias, a situação das fronteiras passou a ser vista como um "problema" para os agentes nacionais, adquirindo maior relevância após a segunda metade do século XIX. As disputas internas de poder entre Buenos Aires, cuja maior parte da arrecadação provinha de seu porto, e as províncias do interior, que demandavam a nacionalização dos recursos dessa aduana, adiaram as questões na fronteira com as sociedades indígenas do Pampa.

Juan Manuel de Rosas era o caudilho representante de uma crescente classe de criadores de gado que cada vez mais clamavam por segurança para seus rebanhos contra os ataques promovidos pelos índios, os chamados malones. Na década de 1830, Rosas efetuou uma operação militar contra os índios do Pampa no intuito de reduzir a apreensão de gado. (FRASKIN, 2009, p. 128) O enfraquecimento dos cacicados indígenas resultante das investidas de Rosas foi superado nas décadas posteriores pela organização dos caciques em grandes confederações.

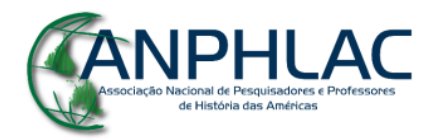

Revista Eletrônica da ANPHLAC, ISSN 1679-1061, №. 22, p. 86-117, Jan./Jun., 2017.

http://revista.anphlac.org.br 
As disputas políticas seguiram durante a primeira metade do século XIX e culminaram em embates diretos entre Rosas, representante de Buenos Aires e o representante das demais províncias, Justo José Urquiza. No ano de 1859, o exército de Rosas foi derrotado pela Confederação Argentina comandada por Urquiza na batalha de Cepeda, marcando o período de divisão do país. A instabilidade econômica, elevada pela manutenção dos recursos da aduana apenas para Buenos Aires e pela incapacidade de conciliação política, levou a uma nova batalha em 1861, Pavón, que culminou com a vitória dos exércitos portenhos e deu início à organização nacional com a capital em Buenos Aires. (SABATO, 2012, p. 68-90)

Poucos anos após o fim das guerras civis, a Argentina entrou em conflito com seus vizinhos, gerando a Guerra do Paraguai (1864-1870), que igualmente impediu o governo de Buenos Aires de colocar em vigor um plano de segurança e expansão de suas terras rumo ao Pampa e à Patagônia. Durante a eclosão do conflito em agosto de 1867, foi aprovada uma lei que previa a ampliação da fronteira até as margens do rio Negro, no início da Patagônia argentina, expulsando os índios para além desse limite. (DE MARCO, 2010, p. 499) A multiplicação dos malones e do estado de insegurança na fronteira pampeana parece ser a explicação mais plausível para a urgência com que o Congresso Nacional argentino aprovou, ainda no ano de 1867, um plano efetivo de incorporação do território austral à jurisdição estatal. Regulamentou-se assim a atuação dos militares na ocupação das margens dos rios Negro e Neuquén como linha de fronteira nacional com os índios.

Com a eclosão da Guerra do Paraguai, a resolução da situação na fronteira interna foi postergada para a década de 1870, limitando as ações do exército à assinatura de tratados de paz com a finalidade de conter a influência indígena, acordar o pagamento regular de bens e víveres aos indígenas (raciones, em espanhol) e fomentar a rivalidade entre os caciques. (NACUZZI, 2010, p. 221) Com os tratados, os caciques comprometeram-se em ceder terras e a realizar novas alianças, estabelecendo uma rede de relações entre os embaixadores caciques e o governo argentino. Sem a possibilidade de avançar o território, os tratados funcionaram como instrumentos de poder sobre os caciques, mas sem representar uma submissão total ao governo. Implicavam perda de autonomia sobre o território, mas garantiam o recebimento de recursos de subsistência. (JONG, 2011, p. 82)

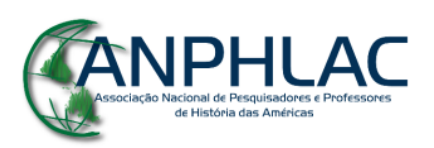

Revista Eletrônica da ANPHLAC, ISSN 1679-1061, №. 22, p. 86-117, Jan./Jun., 2017.

http://revista.anphlac.org.br 
Com o fim do conflito bélico no Paraguai, o governo concentrou suas forças na eliminação e submissão dos índios pampeanos, realizando operações militares para enfraquecer o poderio nativo e promover a definitiva anexação dos territórios do sul. Tal como viria a ocorrer entre os chilenos após a Guerra do Pacífico (1879-1883), os militares argentinos que retornaram do front de batalha para atuar na linha de fronteira do Pampa tiveram o seu "horizonte de expectativas" radicalmente transformado por essa experiência bélica.

Constituindo-se agora enquanto uma instituição profissional, coesa e nacional, o Exército argentino intensificou o investimento em sua modernização. O emprego de novas tecnologias, como os fuzis de repetição Remington, o telégrafo, os navios a vapor e a ferrovia, revolucionaram a forma de guerrear e desequilibraram os combates em prol dos criollos. Além disso, alterou-se o próprio tom do discurso político da geração de veteranos da guerra. Os lentos avanços territoriais e os recorrentes embates contra os indígenas faziam cada vez menos sentido para aqueles que haviam participado de um conflito bélico de dimensões continentais. O projeto "civilizador" criollo tornou-se oposto à sociedade miscigenada da fronteira, uma vez que suas pretensões adquiriram caráter expansionista, sendo incompatível com a manutenção das sociedades indígenas no espaço que pretendia ser incluído ao território do país. (NACUZZI, 2010, p. 237)

Foi apenas no governo de Nicolás Avellaneda (1874-1880) que a lei de 1867 começou a ser executada pelo ministro da Guerra e Marinha, Adolfo Alsina. A partir desse governo, a situação da fronteira interna passou a ser tratada como prioridade, tendo como objetivo promover um avanço gradual da linha de fronteira e da zona de fortes que a acompanhava, realizando a construção de um fosso chamado à época de "zanja". Esse fosso funcionaria como uma trincheira que impediria o trânsito dos índios com o gado das estâncias, até que fosse possível efetuar medidas mais expansionistas sobre as áreas indígenas. Os planos foram interrompidos com a morte do ministro no final de 1877, limitando suas ações basicamente à região de Buenos Aires. Julio A. Roca, que atuava na defesa de um dos pontos de fortificação em Córdoba, substituiu Alsina no Ministério da Guerra e modificou o plano de operações na fronteira ao adotar uma postura mais agressiva contra os índios pampeanos e patagônicos.

Roca começou realizando uma campanha de reconhecimento até que os recursos para uma operação maior fossem liberados, o que ocorreu em 1879. Chamadas de

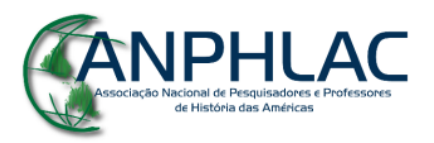

Revista Eletrônica da ANPHLAC, ISSN 1679-1061, №. 22, p. 86-117, Jan./Jun., 2017.

http://revista.anphlac.org.br 
operações preliminares, essas incursões militares pelo Pampa serviram para desestabilizar os principais caciques: Mariano Rosas, Catriel, Pincén e Namuncurá. Esses eram bastante respeitados pelos exércitos, sendo que sua resistência resumiu o contato com as autoridades de fronteira na assinatura de tratados e no pagamento de raciones, buscando impedir os malones.

Ao que tudo indica, a capacidade de resistência das sociedades indígenas do Pampa se reduzia na medida em que os exércitos atuavam em ações mais ofensivas apoiadas nas novas tecnologias e em armamentos mais eficazes. Além disso, essas iniciativas eram sustentadas por entendimentos racistas, ressignificados a partir de discursos de cientistas e intelectuais europeus que relacionavam a civilização com a sociedade branca, excluindo assim as demais raças. (RODRIGUES, 2006)

As sociedades mestiças das fronteiras argentinas passaram a ser vistas como entraves à construção de uma nação civilizada, sendo assim combatidas pelo Estado argentino; e a ideia de expansão da fronteira ao sul era acompanhada da perspectiva de aumento da criação e exportação de gado. (MASSES, 2010, p. 44; DEL RIO, 2005, p.17) Um argumento cultural e outro econômico que convergiam em definir o índio como um "problema" social, tanto pela sua falta de "civilização", dentro do ideal de identidade pretendido pelos argentinos, quanto pela ocupação de espaços produtivos, sem contar com o problema representado pelos malones indígenas para as fazendas de criação de animais.

A não inserção dos indígenas no ideal de identidade dessa nação, que concluía seu processo de consolidação institucional, justificava também o conflito direto gerado pela necessidade de garantir a ocupação dos territórios do Pampa e da Patagônia, uma vez que os discursos eurocêntricos os consideravam livres para uma possível colonização. Essas zonas habitadas por diversas sociedades indígenas eram inseridas na metáfora do "deserto" que atribuía a uma "zona povoada" um sentido de "vazio" de civilização e associavam-na à sua antítese, a barbárie. O "problema” indígena se relacionava, portanto, à formação do território nacional, e a identificação do índio como selvagem serviria para legitimar um projeto nacional territorialista com o objetivo de extender a “civilização” às áreas de controle indígena. (DEL RIO, 2005, p. 63)

Em julho de 1879, a Campanha do Deserto foi finalizada e a fronteira interna foi demarcada no rio Negro, norte da Patagônia argentina. A grande popularidade de Julio

\section{CANPHLAC}

Revista Eletrônica da ANPHLAC, ISSN 1679-1061, №. 22, p. 86-117, Jan./Jun., 2017.

http://revista.anphlac.org.br 
Roca após as expedições no Pampa contribuiu para a chegada do militar na Presidência da República (1880-1886), e as preocupações voltaram-se ao estabelecimento definitivo da fronteira internacional com o Chile na Cordilheira dos Andes. As atividades diplomáticas, em conjunto com as militares, pretendiam garantir a presença argentina sobre os espaços destituídos das sociedades indígenas, e, nesse contexto, o tratado de limites acordado com o Chile em 1881 atestava tais interesses.

Se para chilenos e argentinos a Patagônia era entendida como uma herança da colonização espanhola, para os demais países, sobretudo os europeus, não cabiam reivindicações de soberania por parte de Buenos Aires ou Santiago, uma vez que a região não era ocupada por brancos. Considerados simplesmente como res nullius, muitos países não relacionavam essas áreas com os domínios chilenos ou argentinos, a exemplo dos ingleses, que utilizavam o litoral patagônico como portos de embarcações. Portanto, a assinatura de um tratado, estabelecendo tanto os limites nos Andes quanto os austrais, vinculava-se à garantia de soberania desses dois países frente a outras nações.

\section{Sobre o inimigo interno: territorialização das áreas indígenas}

Não se pode esquecer que o projeto de transposição da linha de fronteiras ao rio Negro envolveu também questões referentes às fronteiras externas da República Argentina, coincidindo assim com o acirramento das disputas limítrofes com o Chile. O agressivo avanço do Estado argentino rumo aos territórios patagônicos chocou-se com os interesses chilenos, visto que a expedição de Roca corria o risco de adentrar em regiões cuja jurisdição era reclamada pelos vizinhos andinos.

A pretensão chilena sobre os territórios austrais foi definida pelo periódico bonaerense La Tribuna ${ }^{3}$ como uma usurpação territorial que, ainda que invocasse um pretexto civilizador, contribuíra, na prática, para a barbarização do espaço. Em contrapartida, o projeto de Julio Roca estaria voltado para a definitiva superação do deserto. Seu intuito seria impor a soberania argentina sobre a vasta região patagônica, mediante o fomento ao seu povoamento e exploração:

\footnotetext{
${ }^{3}$ Fundado em 1853, por Mariano e Héctor Florencio Varela, La Tribuna se constituiu em seus primórdios como representante do oposicionismo portenho ao governo de Justo José de Urquiza.
}

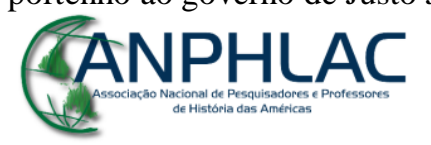

Revista Eletrônica da ANPHLAC, ISSN 1679-1061, №. 22, p. 86-117, Jan./Jun., 2017.

http://revista.anphlac.org.br 
Hay un país en América que ambiciona la gloria de la conquista, y que prevalido de la indolencia de sus vecinos, les han ido arrancado tajadas de territorio desierto. Este país, quien a puesto a raya la actitud decida de despojados, pretendo justificarse ante el mundo alegando razones de civilización y población. Avanzó sobre el Estrecho de Magallanes, protestando el interés de la navegación general, y la urgencia de poblar sus costas desiertas. Han pasado desde entonces muchos años. Que ha hecho Chile en el sentido de cambiar la faz de esos territorios y hacerlos productivos para el comercio y la industria? Donde están las ciudades erigidas, las fábricas planteadas, los puertos, los faros, los canales banalizados, las tribus reducidas? No tiene en todo el Estrecho más que una colonia, y qué colonia, una colonia penal! (La Tribuna, n $^{\circ} 8473,24 / 11 / 1878$, p. 1)

Por esse motivo, a fixação do Exército Expedicionário nas margens do rio Negro em 1879 não representou para Julio Roca a concretização do projeto de territorialização da região austral. Pelo contrário: a bem sucedida ocupação dos Pampas suscitou uma onda de otimismo, segundo a qual nada mais poderia deter a marcha dos regimentos militares vencedores “do deserto e do selvagem”. (La Tribuna, n ${ }^{\circ} 8703,31 / 07 / 1879$ )

Reconhecendo que a República Argentina compreendia também a Patagônia, o Ministro da Guerra julgou imprescindível submeter às leis da Nação os indígenas que habitavam o território compreendido entre os rios Neuquén e Limay e o lago Nahuel Huapi. Ao afirmar incisivamente que "allí iremos buscarlos, aunque se oculten en los valles más profundos de los Andes, o se refugien en los confines de la Patagonia, abriendo así una segunda campaña, donde nuevos trabajos y glorias nos esperan" ( $L a$ Tribuna, $\mathrm{n}^{\mathrm{o}} 8615,29 / 04 / 1879$, p.1), planejou uma nova expedição militar, reforçando o intento de reduzir significativamente a política de tratados de paz. Contudo, na prática, lançou mão de algumas medidas amistosas para conter possíveis resistências orquestradas pelo chefe indígena Valentín Sayhueque, que habitava a região patagônica conhecida como País de las Manzanas. (VEZUB, 2009)

Segundo o correspondente de La Nación, em fins de maio, Roca despachou 27 chasques $^{4}$ rumo às referidas tolderías no intuito de

demostrar los beneficios que ha de reportar a la prosperidad y futuro engrandecimiento de sus respectivas tribus, la influencia protectora de nuestras leyes y las relaciones con las poblaciones que deben crearse al amparo del Ejército. (La Nación, n 2649, 21/06/1879, p. 1)

\footnotetext{
${ }^{4}$ No Império Inca, correspondiam aos funcionários em missão oficial que percorriam a extensa rede viária no intuito de transmitir mensagens.
}

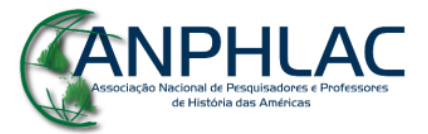

Revista Eletrônica da ANPHLAC, ISSN 1679-1061, №. 22, p. 86-117, Jan./Jun., 2017.

http://revista.anphlac.org.br 
$\mathrm{Na}$ ocasião, foi outorgado a Sayhueque o título de Governador Principal dos Habitantes Indígenas do Deserto, conforme explica o próprio Ministro da Guerra e Marinha:

\begin{abstract}
En cuanto al cultivo de relaciones con las poblaciones de indios amigos, me he limitado en esto a una actitud expectante. El único cacique que he creído merezca por considerado por su conducta siempre fiel y la buena comportación de su tribu que no ha figurado en malones, Sayhueque el de las Manzanas. Me ha dirigido a el imponiéndole clara y terminantemente las reglas de buena amistad y conducta que debe observar por merecer la protección del Gobierno, y le he nombrado gobernador de las Manzanas para que haga cumplir entre las poblaciones indas que allí quedarán bajo su dependencia todas las prescripciones trasmitidas y lo demás que convenga ordenar en lo sucesivo. (La Tribuna, n. ${ }^{\circ} 8663,10$ e 11/07/1879, p. 1)
\end{abstract}

Em carta enviada a Roca e Villegas no mês de agosto, o longko 5 manzanero reforçou a promessa de seguir reconhecendo o poder das autoridades nacionais e de não cooperar com as tribos fugitivas dos pampas:

Es en mi poder su mui importante carta fha 14 de Junio del actual; Con la cual me he impuesto de su Continucion que sus personagues y un numerosos egercitos se hallaban hocupando los puntos Cholechel, Chichinal, y el Neuquen, y todas las pampas, donde bivieron numerosas tribus, desaciendolos y tomandolos pricioneros, por no haber sabidos quienes corresponder aquella generocidad que el Sr. Precidente de la Nacion les habia demostrado; Es verdaderamente amigos que esos crìmenes de malones $\mathrm{y}$ Robos es insufribles he intolerables; de suerte que el que decea cuya opinion pierde todo bien y encuentra con mucha facilidad las desgracias educaciones que me dejo de erencia mi finado padre N. Chocorí manifestando-me en prímer punto. Esto es que en los Crimenes de robos, ho malones, contra cristianos, ho almenos contra buestras tríbus, se resultaban la indignaciones Guerras gravicimamente penosas; de Suerte desgraciada en cuyo origen se pierden todo bien, muriendo ya repentinamente aun el mejor personague familia dejando desgraciadamente guerfanos sin el necesario amparo y perdiendo todos los recursos, lujos, he propiedades legítimas que pocedian sus padres. Con tal motivo amigos Soy de un metodo moral, y me es mui agradable que en la tranquilidad y sociego humanamente se aprobechan infinitos bienes; gozando sus buenas familias, teniendos sus agradables hijos en sus precencías, Sustentandoce bien sin Sucidio ninguno, huzando sus hagradables lujos, durmiendo dulces Sueños a buestro hagrados en su propiedad y leguitima, y como yo a Dios Gracias he llegado aprochar esas opiniones que me dejo Sembrado mi finado padre Chocorí, Religuiozamente cumplo las promezas que tengo contraido desde ya el termino de veinte y tantos años con el Exmo. Señor Precidente de la Nacion y creo indispenzables que el paiz, Superiores, y cuantos actoridades, no tienen puramente nada que esponer contra mi noble persona. (Valentín Sayhueque a Julio Roca e Conrado Villegas, 05/08/1879 In: OJEDA, 2008, p. 718-722)

\footnotetext{
${ }^{5}$ Denominação atribuída à autoridade no seio da família e do grupo indígena.
}

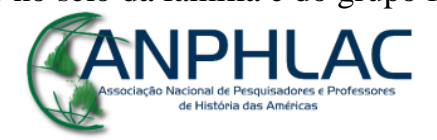

Revista Eletrônica da ANPHLAC, ISSN 1679-1061, №. 22, p. 86-117, Jan./Jun., 2017.

http://revista.anphlac.org.br 
A resistência ao processo de territorialização não era o único aspecto que Roca temia a respeito de Sayhueuque. Também se fazia motivo de preocupação a comunicação mantida pelo longko com os chilenos, fossem eles autoridades criollas ou parentes de origem mapuche.

Além de estimular o comércio ilegal de gado, estimava-se que as relações com os habitantes da porção ocidental da cadeia andina facilitariam a edificação de povoados em territórios reivindicados pela Argentina, colocando em risco a soberania territorial. Nesse sentido, como veremos mais adiante, ainda que se houvesse optado pela arbitragem como solução temporária para os conflitos limítrofes, a tensão com o Chile era latente. Em caso de guerra, o domínio sobre a Patagônia habilitaria as tropas argentinas a operar sobre Punta Arenas e a tomar posse do Estreito de Magalhães, garantindo a rápida penetração em território chileno.

Conforme nos conta o próprio manzanero, Roca chegara a lhe solicitar que não se relacionasse com estrangeiros ou índios chilenos e não os admitisse como lenguaraces em suas tolderias. Este último pedido, entretanto, foi prontamente rechaçado por Sayhueque:

Y al mismo tiempo me encarga que no me deje engañar de acectar relaciones de las Autoridades Chilenas me dice como se a dejado engañar algunos de mis cacíquez de las faldas de las cordilleras y al mismo tiempo igualmente me encarga que mis comiciones no los inbie con ningun estrangeiro ni como cer con ningun indio de chileno de lenguaras todo estos fundamentos los encuentro mui pocitivo i mui ecencial; Hunicamente mi Secretario Señor Loncochino y un capitanejo lengu[a]ras no puedo carecer en mis jurisdiciones; Esto es; para dirigir mis obgetos a esos destino ya cea a Buenos Ayres es decir para podernos comprender perfectamente buestras correspondencias de manera cuando me dirijo á algun Superior precizamente se redactan mis entendimientos. (OJEDA, 2008, p. 718-722)

Assim como Namuncurá, Sayhueque foi capaz de preservar a sua soberania até o ano de 1881 quando Roca, agora Presidente da República, ordenou a realização das expedições ao lago Nahuel Huapi e ao sul do rio Limay. Para que a conquista da Patagônia fosse colocada em prática, em muito contribuiu o sucesso da Campanha do Deserto de 1879 e, consequentemente, a empatia desenvolvida pela opinião pública à figura do general.

\section{GANPHLAC}




\section{Sobre o inimigo externo: a Guerra do Pacífico e a afirmação do Chile no cenário internacional}

No que diz respeito ao Chile, os anseios expansionistas estatais impediram que os projetos elaborados pelos militares Cornelio Saavedra e Gregorio Urrutia para a conquista da Araucania ${ }^{6}$ alcançassem resultados expressivos. Isso porque uma disputa de soberania travada com a Bolívia e com o Peru veio a deflagrar em 1879 a Guerra do Pacífico.

A origem do conflito bélico remonta aos interesses econômicos sobre o litoral do Deserto do Atacama e aos dissensos acerca da jurisdição a ser exercida sobre seu território, que se estende até o rio Salado ou Paposo, aos $25^{\circ} 30^{\prime}$ de latitude. Em virtude das escassas riquezas produzidas pela região na época colonial, as primeiras constituições chilenas determinaram o deserto como a fronteira norte da república, respeitando as antigas delimitações existentes entre o Vice-Reinado do Peru e a Capitania-Geral do Chile.

Contudo, em 1842, o início da exploração do guano levou o governo chileno a criar a Província do Atacama, suscitando a insatisfação do governo boliviano. Reforçando um acordo estabelecido em 1866, o tratado aprovado em 06 agosto de 1874 definiu os limites entre os dois países pelo paralelo $24^{\circ}$ de latitude sul, a divisão das rendas relativas à exportação do guano e de minerais extraídos entre os paralelos $23^{\circ} \mathrm{e}$ $25^{\circ}$ e, por fim, a não sujeição de pessoas, indústrias e capitais chilenos a contribuições de qualquer tipo, além daquelas que eram comumente cobradas. O Imperador do Brasil foi designado árbitro das possíveis divergências sobre a execução do tratado. Todavia, as relações bilaterais não deixariam de ser marcadas pela instabilidade desde então. (SANTOS, 2002)

A burguesia chilena tinha interesse, em especial, em resguardar os investimentos que há muitos anos concentravam-se no norte: primeiro na exploração da prata, depois do cobre e finalmente do guano e do salitre. Desde 1873, a Companía Anónima de Salitre y Ferrocarril de Antofagasta havia se convertido em proprietária de terrenos no Atacama e livre de toda contribuição fiscal ou municipal.

\footnotetext{
${ }^{6}$ Situada a $667 \mathrm{~km}$ de Santiago, a Araucania possui como limites geográficos o Bio-Bio ao norte, a região dos Lagos Andinos ao sul, a República Argentinaa leste e o Oceano Pacífico a oeste.
}

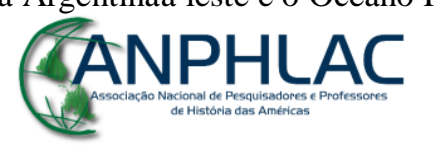

Revista Eletrônica da ANPHLAC, ISSN 1679-1061, №. 22, p. 86-117, Jan./Jun., 2017.

http://revista.anphlac.org.br 
Contudo, a meta dos empresários chilenos foi diretamente atingida por duas decisões arbitrárias do governo boliviano. Em 14 de fevereiro de 1878, estabeleceu-se uma nova taxa de 10 centavos sobre cada quintal de salitre exportado; em janeiro de 1879, anularam-se as concessões de terrenos salitreros e de boratos realizadas pelos governos antecedentes, submetendo a leilões todas as propriedades consideradas ilegítimas.

Para o encarregado da legação chilena, P. N. Videla, tais decisões feriam o tratado de limites de 6 de agosto de 1874. Em um reclamo redigido ao Ministro das Relações Exteriores da Bolívia, Francisco Valdés Vergara, ressaltou que o desagravo à lei frustrava suas expectativas quanto ao alcance de uma solução tranquila e conciliadora para a questão, já que inviabilizava as negociações diplomáticas entre Chile e Bolívia. Na ocasião, responsabilizou exclusivamente o governo boliviano por quaisquer consequências nefastas porvindouras. (El Mercurio, 19/12/1878, p. 1)

A completa cobertura dos eventos ocorridos desde o agravamento das tensões entre os dois países até a ocupação militar do Deserto de Atacama pelo Chile foi realizada por $E l$ Mercurio $^{7}$ através da publicação de editoriais, da reprodução de documentos oficiais intercambiados entre os dirigentes estatais e do acompanhamento da repercussão do conflito na imprensa peruana e argentina.

Desde o início, o periódico considerou a insatisfação expressa pelos empresários chilenos como justa e legítima, dada a centralidade assumida pelo capital chileno investido em Antofagasta - o qual, segundo cálculos, ultrapassara os 5 milhões de pesos - no desenvolvimento da região. "Escuelas, muelle, caminos, casas, medios de movilización marítimos y terrestres, afluencia da población, de nuevas industrias y negocios", afirmou o autor de La cuestión boliviana ante los hechos y la historia, "tales han sido los frutos de la obra de esa sociedad, hoy embargada, apremiada y perseguida por los mismos a quienes vino a traer los dones de la fortuna y del trabajo". (El Mercurio, 18/01/1879, p. 1)

Entretanto, é interessante salientar que o diário manteve nesse primeiro momento um posicionamento contrário à guerra contra a Bolívia. Defendeu o

\footnotetext{
${ }^{7}$ Fundado em 1827 por Pedro Félix Vicuña, Thomas Wells e Ignacio Silva, El Mercurio foi um diário pioneiro do mundo de língua hispânica; transcendeu seu tempo e pode ser encontrado ainda hoje no Chile.
}

\section{BANPHLAC}

Revista Eletrônica da ANPHLAC, ISSN 1679-1061, №. 22, p. 86-117, Jan./Jun., 2017.

http://revista.anphlac.org.br 
argumento de que o Estado chileno deveria perseguir uma mínima coerência em sua política externa, aplicando às questões internacionais medidas que não variassem de acordo com a força ou a debilidade dos adversários enfrentados. Para tanto, seria necessário solucionar o conflito com o governo boliviano adotando um caminho semelhante àquele seguido no caso argentino. Tal raciocínio encontra-se expresso no artigo Ayer y hoy:

No fuimos nosotros los inconsecuentes, sino aquellos que condenaban la guerra como un crimen cuando se trataba de los territorios del sur y la presentan como una necesidad ahora que se trata de los salitres del norte. Nosotros decimos que si era un crimen hacer la guerra a la República Argentina, debe serlo también la guerra a Bolivia, sobre todo siendo esta incomparablemente menos fuerte que aquella. (El Mercurio, 23/01/1879, p. 1)

Ademais, El Mercurio argumentava que aqueles que defendiam a guerra contra a Bolívia eram os mesmos que anos antes haviam condenado a guerra contra a Argentina, considerando-a um "grande crime americano". De acordo com a comparação traçada pelo periódico, o conflito com a Argentina decorrera do exercício de atos de jurisdição e de soberania em territórios chilenos, implicando em uma violenta agressão à honra da nação. Já os desajustes com o governo boliviano teriam gerado exclusivamente prejuízos financeiros, cujo valor simbólico seria infinitamente inferior à cessão de territórios à Argentina. Se o conflito limítrofe na cadeia andina fora solucionado por meios pacíficos, caberia agora ao Estado chileno esgotar os recursos conciliadores antes de voltar-se para o emprego da força militar.

Em fevereiro de 1879, a notícia da chegada de tropas bolivianas a Caracoles e de sua movimentação em direção ao litoral suscitou rumores de que a Bolívia se preparava para a guerra. A partir de então, podemos identificar uma importante inflexão no discurso político apresentado por $\mathrm{El}$ Mercurio. Embora considerasse a guerra “incompatível com a alta civilização do século", parecia cada vez mais convencido da imprescindibilidade de sua ocorrência. A obstinação do governo boliviano em buscar um desenlace violento para o conflito era agora interpretada como uma violação à dignidade do Chile e, na avaliação do periódico, caberia a qualquer nação "derramar até a última gota de sangue antes de aceitar uma humilhação" (El Mercurio, 23/01/1879, p. $1)$.

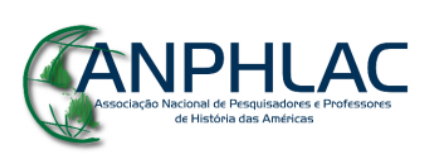

Revista Eletrônica da ANPHLAC, ISSN 1679-1061, №. 22, p. 86-117, Jan./Jun., 2017.

http://revista.anphlac.org.br 
Claramente, a preocupação estava em assegurar a posição soberana do Chile no continente americano: para tanto, fazia-se necessário frisar que o país não se sujeitaria às servidões e caprichos das repúblicas vizinhas. Foi nesse sentido que o autor de Someterse o resistir lançou o seguinte questionamento:

\footnotetext{
¿Qué puesto ocuparíamos en América cuando nos hubiéramos colocado a los pies de Bolivia y de la República Arjentina? Seríamos objeto de lastima, y por cierto que habríamos merecido mucho mereciendo siquiera compasión. (El Mercurio, 10/02/1879, p. 1)
}

E, concluindo o seu raciocínio, afirmou: "No deseamos la guerra con Bolivia; pero si Bolivia nos provoca debemos hacerla, cueste lo que cueste" (El Mercurio, 10/02/1879, p. 1).

A oficialização da Guerra do Pacífico deflagrou a constituição de um sistema de alianças militares que envolveram direta e indiretamente outros países do continente. Diante da inversão de uma quantia considerável do Tesouro Nacional e do emprego da força bélica na expedição ao Rio Negro, e após as negociações travadas com os representantes chilenos, o governo argentino optou pela neutralidade no conflito. Contudo, não deixou de expressar o temor quanto às consequências de uma possível vitória do Chile, a qual the permitiria exercer uma preponderância absoluta no Pacífico, desde Antofagasta até o Estreito de Magalhães. O posicionamento crítico assumido pela imprensa argentina perante a guerra reflete a circulação de comentários acerca dos riscos de violação dos limites territoriais estabelecidos pelo Pacto Fierro-Sarratea. Conforme esclarece o periódico La Republica,

\footnotetext{
Nosotros no predicamos la guerra, no la queremos; pero queremos que Chile nos haga justicia; queremos que corresponda a la lealtad del gobierno argentino, queremos que no nos sacrifique, y que defina y concluya la cuestión de límites que nos ha promovido; queremos, finalmente, que no haga jugar a la República Argentina un papel ridículo, impidiéndole toda acción durante y después de la guerra de Pacífico, y dejándola envuelta, al mismo tiempo, en su eterna y enojosa cuestión de límites, a pretexto del pacto de diciembre. (El Mercurio, 17/04/1879, p. 1)
}

Entretanto, é sabido que a desconfiança nutrida em relação aos interesses expansionistas chilenos não proveio apenas da Argentina. Em 1873, o Ministro das Relações Exteriores do Peru, Riva Agüero, firmou um tratado secreto com a Bolívia

\section{GANPHLAC}

Revista Eletrônica da ANPHLAC, ISSN 1679-1061, №. 22, p. 86-117, Jan./Jun., 2017.

http://revista.anphlac.org.br 
cujo intuito era resguardar o litoral boliviano das usurpações que o governo chileno pretendia levar a cabo, com possível prejuízo do território peruano.

Partindo da mesma lógica de raciocínio, a elite letrada e a opinião pública no Chile consideravam que a ruptura das relações diplomáticas com a Bolívia poderia deflagrar um conflito americano, expressando por isso certo temor quanto a uma possível coalisão entre Peru, Bolívia e Argentina. Ainda que no início do conflito $E l$ Mercurio reduzisse o papel das repúblicas do continente ao de "expectadores da guerra", chegara a mencionar que

no faltan entre los alarmistas quienes aseguren que se há firmado por ahí una triple alianza cuyo objeto seria moderar las invasiones chilenas y destruir la preponderancia de este país en el continente. (El Mercurio, 21/02/1879, p. 1)

Sabemos que a postura inicial do governo peruano foi a neutralidade no intuito de evitar um desenlace violento para o conflito. Contudo, as hostilidades progressivamente caminharam rumo a um desfecho bélico. A influência da imprensa peruana e dos jurisconsultos civilistas sobre a política do presidente Mariano Prado, além dos rumores sobre o tratado secreto assinado com a Bolívia, agravaram o clima de instabilidade política e levaram o Chile a declarar oficialmente guerra ao Peru no mês de abril. (VILLALOBOS, 1996)

Mais uma vez, o caráter assertivo da decisão tomada pelo governo chileno foi sustentado por El Mercurio. Segundo o periódico, a falta de honestidade e de decoro de Mariano Prado abrira brechas a uma vingança tão terrível quanto o insulto sofrido. "Que los degenerados descendientes de los Incas reciban el castigo que merecen por su traición cobarde, por su envidia ruin, por sus odios inveterados y gratuitos contra Chile" (El Mercurio, 02/04/1879, p. 1), clamou o autor de ;A la guerra! ¡A la guerra!

Em termos discursivos, tal artigo faz-se bastante interessante na medida em que promove uma significativa transformação da representação imagética da Araucania e de seus habitantes. Desde meados do século XIX, os araucanos foram descritos pela imprensa chilena como "índios bárbaros e sanguinários" por serem identificados como inimigos internos do projeto de incorporação da Araucania à jurisdição estatal. Contudo, durante a Guerra do Pacífico, tal como ocorrera no contexto independentista, tornou-se conveniente a adoção de um discurso político que recuperasse a força e a bravura dos mapuche. A valorização da "indomável raça indígena" apresentava-se como uma forma

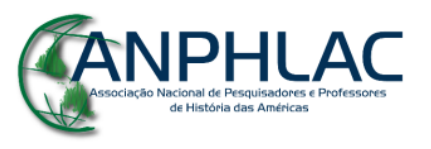

Revista Eletrônica da ANPHLAC, ISSN 1679-1061, №. 22, p. 86-117, Jan./Jun., 2017.

http://revista.anphlac.org.br 
profícua de ressaltar a superioridade do povo chileno ante o inimigo externo, fosse a Espanha, o Peru ou a Bolívia, como fica evidente no trecho a seguir:

El Perú nos lleva la ventaja de la premeditación, pero nosotros les llevamos la del denuedo, la del empuje irresistible de nuestros soldados, en cuyas venas circula la sangre de fuego del español mezclada con la lava de los volcanes de Arauco. Pizarro degolló como a ovejas en la plaza de Lima a los miles de indios que custodiaban el palanquín de Atahualpa; Valdivia no pudo matar un solo araucano impunemente; aquellos eran menos que mujeres, estos mucho más que hombres, eran todos titanes del patriotismo. Las afiladas tizonas españolas se mellaron en el pecho de granito de los hijos de Chile, mientras que en la sedosa piel de los Incas no hicieron más que afilarse más. ( $E l$ Mercurio, 02/04/1879, p. 1)

Portanto, através da mobilização de temas patrióticos, o periódico de Valparaíso ressaltou as qualidades do povo chileno ao incitá-lo a combater valentemente seus inimigos, retratados como inferiores e frágeis.

A partir da definição do sistema de alianças e do envolvimento oficial do Peru no conflito, a Guerra do Pacífico converteu-se para El Mercurio em uma questão de preservação da dignidade nacional. Afinal, para o periódico, o que estava em jogo não era apenas o território disputado, mas também o exercício da soberania plena no continente americano. Daí a profusão de artigos que incitavam o espírito bélico e pressionavam o presidente Aníbal Pinto por medidas capazes de assegurar o triunfo do Chile. A divisa era basicamente vencer ou morrer:

\footnotetext{
¿O cree el jefe de Estado que un desastre no sería una ruina total y eterna de Chile? ¿Cuáles serían las fronteras de nuestro país, si por desgracia la coalición Perú-boliviana nos hiciese sentir el peso de su victoria? Por el norte tendríamos Copiapó como límite, y por el sur no tardarían los argentinos en hacernos replegar sobre Chiloé. Y sobre quedar desmembrado nuestro territorio, vendían la pobreza suma, el descredito eterno, y la retrogradación moral, consecuencia precisa de aquel cataclismo. En cambio vencedores, nuestra suerte sería la de un pueblo rico, fuerte, prestigioso; seriamos los dominadores del Pacífico, y a la sombre de ese dominio podríamos dar a Bolivia lo que le ha arrebatado su tierna hermana de última hora y asegurarle, no una existencia mendicante como la que ahora tiene, sino la vida propia de un pueblo libre. Sofocada como esta por falta de aire respirable, emparedada, diremos mejor, dejaría de ser la mansión de los dictadores bucaneros, de los piratas de uniforme, para convertirse en asilo de la paz y del trabajo. ( $\mathrm{La}$ Republica, 14/04/1879, p. 1)
}

Em janeiro de 1881, a vitória das tropas chilenas nas batalhas de San Juan e Miraflores garantiu a tomada da cidade de Lima. Até a sua finalização oficial, no ano de 1883, a Guerra do Pacífico viu-se reduzida a pequenos confrontos localizados. O cunho

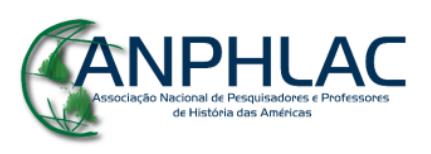

Revista Eletrônica da ANPHLAC, ISSN 1679-1061, №. 22, p. 86-117, Jan./Jun., 2017.

http://revista.anphlac.org.br 
político-diplomático assumido pelo conflito a partir de então permitiu o retorno de parte considerável do contingente militar ao Chile, sobretudo de oficiais que haviam assumido um papel de destaque nas obras de Pacificação da Araucania, como Cornelio Saavedra, Basilio e Gregorio Urrutia e Pedro Lagos.

Fato é que a Guerra do Pacífico havia sido responsável pelo afastamento do Exército chileno do guarnecimento da fronteira araucana, função temporariamente assumida pela Guarda Nacional. Tal situação deixou a região exposta a interesses particulares, em prejuízo dos indígenas e dos projetos de expansão territorial anteriormente colocados em prática. $\mathrm{O}$ estado de inquietude na zona de Traiguén viria a ser agravado pelo assassinato de Domingo Meliñ e de seus familiares, em setembro de 1880, em virtude de um roubo de cavalos.

Contudo, a vitória do Chile na guerra trouxe consigo o fôlego necessário à resolução da questão araucana no país. Conforme explica José Bengoa (2000), o avanço em direção ao norte e a entrada triunfante em Lima provocaram uma onda de entusiasmo, confiança e orgulho nacional que contagiou o governo de Santiago e a opinião pública. Tornou-se evidente para os diversos setores da sociedade chilena a possibilidade de ocupar definitivamente o território nacional mediante o enfrentamento das disputas limítrofes com a Argentina e a vitória sobre os mapuche. Tal estado de espírito encontra-se expresso na seguinte correspondência de fronteira publicada por $E l$ Ferrocarril, que estabelece uma comparação entre a Guerra do Pacífico e as campanhas contra os índios:

Muchos creen que la campaña de la frontera por ser contra los indios no tiene ningún mérito y que si la del norte ofreció laureles y coronas, esta, por lo contario, no ofrece más que hambres y privaciones de todo jénero. Pero los que así piensan, piensan sin lójica y se separan de la verdad. La campaña del norte fue para contestar al reto de muerte lanzado contra Chile por los dos pueblos que llamándose hermanos habían en secreto suscrito un pacto de ignominia, amenazando así nuestra integridad territorial. La campaña del sur es un dique a las devastaciones de los indígenas logrando someter a la civilización a los que tiene estacionario y sin vuelo el comercio del sur, fuente inagotable de riquezas para el país y para la humanidad. La primera tendió a hacer cesar la envidia y la mentira y la segunda es para llevar la luz al antro, al caos que se llama Araucania, y que en pleno siglo XIX existe todavía como un reto lanzado al progreso que hemos alcanzado. Esta última no ofrece cintas ni medallas, pero los que en ella toman parte abrigan la convicción de hacer un servicio no solo a la patria, sino también a la humanidad toda. (El Ferrocarril, n ${ }^{\mathrm{o}} 7959,6 / 02 / 1881$, p. 1, grifos nossos)

\section{GANPHLAC}

Revista Eletrônica da ANPHLAC, ISSN 1679-1061, №. 22, p. 86-117, Jan./Jun., 2017.

http://revista.anphlac.org.br 
Portanto, em janeiro de 1881, elementos imprescindíveis à conquista da Araucania encontravam-se disponíveis no Chile: um Estado forte e um Exército moderno, este último amparado por equipes de saúde (médicos e enfermeiros), material de construção e trabalhadores especializados no levantamento de fortes, instalação de telégrafos, fundação de povoados. Antes do término de sua administração, Aníbal Pinto encarregou Cornelio Saavedra, Gregorio Urrutia e Manuel Recabarren, Ministro do Interior, da realização das operações militares nas linhas do Traiguén e do Cautín.

Após a entrada do exército chileno na capital do Peru, ocasião que determinou a vitória chilena na Guerra do Pacífico, as negociações relativas à definição da fronteira foram então retomadas. Em certos núcleos políticos argentinos, pairavam dúvidas sobre as atitudes da chancelaria chilena após o triunfo no Pacífico (Carta de Juan Torrent a Rufino de Elizalde. Corrientes, 25/01/1881), encarando a resolução do litígio como prioridade.

\section{Sobre os limites internacionais}

As tensões diplomáticas ocorridas no período que se estendeu entre a segunda metade do século XIX e princípios do século XX envolvendo os Estados argentino e chileno podem ser explicadas pelos conceitos de "equilíbrio de poder" e "zonas de influência”. (LACOSTE, 2004, p. 36) A definição dos territórios correspondentes a cada país implicou disputas diplomáticas que refletiam as pretensões de ambos em afirmar seu poder a nível regional e em evitar possíveis conflitos ou expansões territoriais.

Uma vez efetuada a conquista dos territórios austrais, as preocupações foram se voltando para a definição dos limites internacionais. Retomando os antecedentes da questão de limites entre as duas repúblicas, um tratado firmado em 1856 definiu o parâmetro para as negociações fronteiriças. O "principio de derecho internacional positivo americano", o uti possidetis, foi estipulado como válido para a situação dos limites entre Chile e Argentina, definindo que os territórios de ambas as repúblicas deveriam respeitar as jurisdições anteriores a 1810, sendo que o Chile permaneceria com as possessões no Pacífico e a Argentina, no Atlântico.

De acordo com o governo argentino, os chilenos afirmavam que seu país possuía a jurisdição das áreas situadas ao sul do rio Santa Cruz, incluindo a Terra do Fogo e

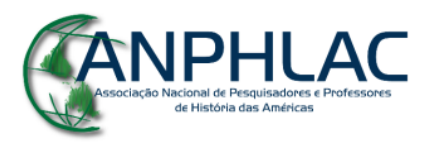

Revista Eletrônica da ANPHLAC, ISSN 1679-1061, №. 22, p. 86-117, Jan./Jun., 2017.

http://revista.anphlac.org.br 
ilhas adjacentes ao Estreito de Magalhães. Os argumentos chilenos eram sustentados pelas afirmações de que essas áreas pertenciam ao país durante o período colonial, sendo que a Argentina possuía afirmações semelhantes. A denúncia do envio de legações chilenas às áreas orientais dos Andes no ano de 1875 foi seguida pela criação da Gobernación de la Patagonia pelo governo argentino, em tentativa de colocar as áreas indígenas dentro da jurisdição do país. (BANDIERI, 2009)

Além das divergências de posições sobre a soberania da Patagônia, as dificuldades em chegar a uma posição sobre os limites eram aumentadas pelo desconhecimento das áreas em litígio. Apesar das discussões realizadas e dos informes trocados, os dois países permaneciam em um impasse e as novas negociações apenas ratificavam que "el gobierno argentino y el de Chile estaban de acuerdo que los Andes nos dividían. Toda la cuestión estaba en saber por donde corrían." (La Libertad, 11/07/1878, p. 1) Entre as principais discordâncias estava à definição do status quo de cada país, que se referia ao princípio que seria utilizado para efetuar a demarcação dos limites. Desde a década de 1850, falava-se no princípio de "divisão de águas" que definiria o limite pelas áreas banhadas pelo oceano Atlântico ou Pacífico, mas que geravam dúvidas a respeito dos rios que nasciam em um território, mas que desaguavam no oceano que se localizava no lado oposto da Cordilheira dos Andes. (ENCINA, 1986, p. 11)

As discussões sobre o status quo foram retomadas na década de 1870 por Barros Arana pelo Chile e Rufino de Elizalde pela Argentina. Dentro da dificuldade em precisar os rios como "chilenos" ou "argentinos", foram discutidas as alterações do status quo para "os picos mais altos dos Andes". No entanto, o desconhecimento da região somada à impossibilidade de definir os limites pelos picos mais altos da cordilheira, aumentou a tensão entre os dois países.

O impasse entre Elizalde e Barros encaminhou a questão para uma arbitragem internacional e o rei da Bélgica estabeleceu as regras para a arbitragem, como mostra o trecho abaixo:

Art. $4^{\circ}$. El árbitro tendrá el carácter de árbitro juris, que ambos gobiernos le confieren. El árbitro fallará en ese carácter y con sujeción: $1^{\circ}$. A los actos y documentos emanados del gobierno de España, de sus autoridades y agentes en América, y a los actos y documentos procedentes de los gobiernos de la república de Chile y de la Argentina; $2^{\circ}$. Si todos eses actos y documentos no

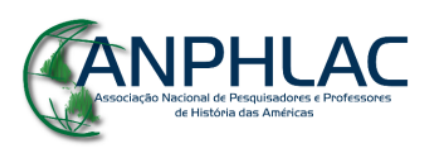

Revista Eletrônica da ANPHLAC, ISSN 1679-1061, №. 22, p. 86-117, Jan./Jun., 2017.

http://revista.anphlac.org.br 
fuesen bastante claros para resolver por ellos las cuestiones pendientes, el árbitro podrá resolverlas aplicando también los principios de derecho internacional. Art. 5o. Dentro del plazo de dos meses después de ratificado este tratado, el gobierno de Chile entregará al Argentino en Buenos Aires y el argentino al de Chile en Santiago, las memorias sobre las pretensiones respectivas y las razones en que las fundan, estando obligados a comunicarse recíprocamente los antecedentes que invoquen y que se pidieran por uno a otro. Seis meses después, y en la misma forma anterior, se entregarán las contra-memorias. Constituido al arbitraje, ambos gobiernos podrán hacerse representar ante el árbitro por los plenipotenciarios que crean convenientes, para dar los informes que se les pida, para gestionar los derechos de sus países respectivos y para asistir a las discusiones a que puedan ser invitados por el árbitro. (La Nación, n ${ }^{\circ} 2364,06 / 07 / 1878$, p. 1)

Diante da impossibilidade de resolução do litígio, principalmente sobre os canais do Estreito de Magalhães e as regiões pouco conhecidas da Patagônia, a decisão final esperaria a resolução de árbitros internacionais, após uma avaliação mais rigorosa dos documentos oriundos da Coroa espanhola, do Vice Reino e da Capitania do Chile. Até que fosse definido o limite pela arbitragem final, a divisão entre os dois países se daria nos Andes, respeitando o princípio do divortia aquarum ou divisão de águas, em que os territórios banhados pelo oceano Atlântico pertenceriam à Argentina, da mesma forma que as porções com margens no Pacífico fariam parte da jurisdição chilena.

Após anos de negociações diplomáticas, Rufino de Elizalde e Diego Barros Arana apenas conseguiram estabelecer uma solução provisória para essa questão: definir os limites nos Andes e encaminhar o impasse para os árbitros internacionais. Contudo, o rechaço do governo chileno aos convênios previamente estabelecidos comprometeu as relações diplomáticas entre os dois países. Segundo a avaliação feita por La Nación, à intenção inicial do Chile nunca fora fazer valer a arbitragem:

La verdad es que el Tratado se hizo con arreglo a instrucciones, con la aprobación previa del gobierno de Chile, y que después este le ha desaprobado por otras razones. ¿Qué razones son estas? Tal es el problema a resolver. Para nosotros, la razón principal es que Chile no quiere arbitraje bajo ninguna forma; que firmó y aprobó el Tratado en la esperanza de dejarlo sin efecto por la transacción; y que cuando se persuadió de que esta no era posible, desaprobó el Tratado, que había aprobado en la expectativa, colocándose en la situación difícil en que se encuentra [...] La política del Gobierno Argentino fue, por el contrario, constituir el arbitraje, arreglando los incidentes, y prescindiendo de la transacción, como dependiente de la cuestión principal, para tratarla por separado. Encerrada la negociación en este círculo de fierro, el Gobierno de Chile se prestó a constituir el arbitraje a más no poder, en la esperanza de una transacción o limitación de arbitraje. Perdida esta esperanza por las proposiciones hechas, desaprobó el tratado. (La Nación, n ${ }^{\mathrm{o}} 2366,09 / 07 / 1878$, p. 1)

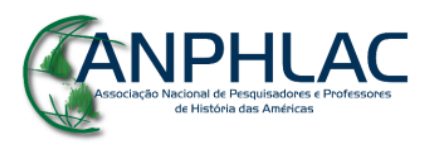

Revista Eletrônica da ANPHLAC, ISSN 1679-1061, №. 22, p. 86-117, Jan./Jun., 2017.

http://revista.anphlac.org.br 
Demarcar os limites exteriores era uma forma de prevenir uma possível atitude hostil por parte do Chile. Houve, então, uma tendência a procurar a resolução da questão pelas vias da conciliação, demonstrando a intenção de elaborar um novo tratado ratificando as propostas que já vinham sendo discutidas e promovendo a negociação das áreas em litígio, conforme pode ser inferido em periódico do período:

desde hace varios meses y con incansable voluntad, se cruzan telegramas y comunicaciones que han ido reduciendo los puntos en litigio hasta que se ha llegado á una solución. Las bases convenidas son propiamente de un tratado definitivo de límites. (La Tribuna, 06/1881, p. 1)

O tratado de limites entre os dois países foi acordado no dia 23 de junho de 1881 tomando por base o artigo $39^{\circ}$ do tratado redigido em 1856, estipulando que ambos os países aceitariam tomar por base as áreas em posse do Vice-Reinado e da Capitania do Chile para a efetuação de suas fronteiras. Resolveram-se os principais pontos do litígio, especialmente sobre a jurisdição da Terra do Fogo e do Estreito de Magalhães.

$\mathrm{Na}$ intenção de conservar os "limites naturais", implícitos no princípio da “divisão de águas”, o tratado procurava precisar as jurisdições referentes a um e ao outro país, principalmente nas áreas de litígio. Apesar de ainda se basear em informações com escassa comprovação, culminando na persistência de dispositivos vagos, tais como "altas cumbres de los andes" e o curso dos rios na cordilheira e seus afluentes que desaguassem no Pacífico ou no Atlântico, o tratado representava uma tentativa de precisar a fronteira internacional.

Com a assinatura do tratado, as pretensões chilenas no Estreito foram confirmadas, assim como a posse da Patagônia pela Argentina. A Terra do Fogo foi dividida entre os dois países, assim como as ilhas próximas, considerando que aquelas a ocidente da divisão ficariam com o Chile, e as dispostas na parte oriental caberiam à Argentina. É provável que resguardar o país da possibilidade de uma guerra estivesse entre as intenções de demarcar os limites nos Andes. Com a vitória chilena no Pacífico, existia certa preocupação com a probabilidade de um conflito armado, tendo em vista a ocupação das zonas de litígio. Periódicos e setores da elite política argentina trabalhavam com essa hipótese, o que atrelava o Tratado de 1881 às intenções estratégicas desse governo. Do outro lado da cordilheira, o presidente do Chile defendia que a assinatura do tratado significaria a redução das possibilidades de guerra, atitude

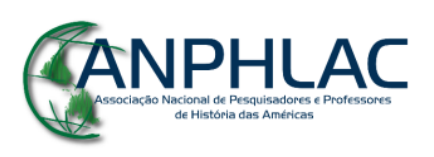

Revista Eletrônica da ANPHLAC, ISSN 1679-1061, №. 22, p. 86-117, Jan./Jun., 2017.

http://revista.anphlac.org.br 
benéfica para a situação existente com seus vizinhos do norte: "debería llevarse adelante el asunto tal como está arreglado, puesto que la paz con la Argentina nos va a facilitar la manera de entendernos con el Perú y Bolivia.” (Carta de Domingo Santa Maria a Aníbal Pinto, 16/07/1881 apud CISNEROS, 1998, p. 262)

Dentre os discursos sobre as Campanhas do Deserto, levar as tropas argentinas até o Negro teve a finalidade de proteger o país de um ataque chileno pelo território indígena, uma vez que os índios pampeanos eram considerados aliados do Chile pelo vínculo comercial existente. A ocupação do Pampa e da Patagônia, dentro dessa perspectiva, procurava conter a influência chilena com a ocupação militar, como pode ser verificado nas palavras do militar Manuel Olascoaga, ao descrever os antecedentes das operações militares no rio Negro:

\begin{abstract}
continuando las fronteras como estaban, un ejército chileno hubiera podido pasar impunemente la cordillera, tomando posesión del Rio Negro y lanzando una nube de barbaros protegidos por tropas regulares, en nuestra dilatada frontera. (El Hispanoamericano, 15/06/1881, p. 1)
\end{abstract}

Juntamente com a confirmação do tratado, peritos chilenos e argentinos foram encarregados de percorrer os caminhos dos Andes procurando sanar as dificuldades existentes na demarcação da fronteira que fossem decorrentes de irregularidades no terreno ou em lugares de difícil aplicação do princípio da “divisão de águas". A arbitragem estrangeira seria utilizada caso os peritos não chegassem a um acordo, conforme acordado pelos representantes dos dois países, Francisco de Echeverría, pelo Chile, e Bernando de Irigoyen, pela Argentina.

No entanto, efetuar as demarcações dos limites, conforme estipulado em 1881, não foi tão simples quanto o texto do tratado: "la línea fronteriza correrá en esa estension por las cumbres mas elevadas de dichas cordilleras que dividan las aguas y pasará por entre las vertientes que se desprenden a uno lado y otro." ${ }^{8}$ No momento de sua elaboração, pouco se conhecia das paisagens austrais, inclusive daquelas em litígio, a exemplo dos territórios de Santa Cruz e Terra do Fogo.

Foi apenas com as operações militares contra os índios da Patagônia e da Araucania, recorrentes a partir de 1880, que muitas das áreas foram conhecidas,

\footnotetext{
8 Artigo $1^{\circ}$, Tratado de limites de 1881. Disponível em: http://www.bcn.cl/lc/tinterna/tratados_pdf/ tratado_vally107.pdf Acesso em: 26 de julho de 2015.
}

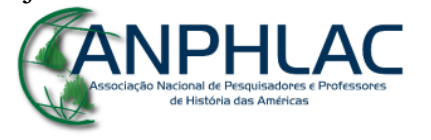

Revista Eletrônica da ANPHLAC, ISSN 1679-1061, №. 22, p. 86-117, Jan./Jun., 2017.

http://revista.anphlac.org.br 
agregando mais questões ao litígio. A utilização de dois critérios para a definição da linha de fronteira - "picos mais altos" e "divisão de águas" - ocasionou controvérsias, já que em muitos trechos da cordilheira houve dificuldades em definir a "linha" entre a morfologia dos Andes e seus inúmeros rios e afluentes.

As duas referências expressas no tratado de 1881 davam margens a muitas interpretações, pois não era indicado se um princípio prevaleceria em relação ao outro, ou se os dois deveriam ser colocados em questão. Em ambos os casos, a demarcação de limites seria pautada por parâmetros imprecisos, ocasionando a necessidade da convenção de 1888. (CISNEROS, 1998, p. 18) Nessa situação, foram definidas as comissões de limites com os peritos que atuariam na intenção de promover a demarcação.

Ao colocar a resolução da situação limítrofe por um tratado fixado mais por convenções geopolíticas do que pela atestada possibilidade de fixação da fronteira, a questão permaneceu praticamente inalterada na década de 1880. Pode-se entender que o tratado de 1881 foi uma forma de impedir a eclosão de um conflito armado, em que ambas as partes cederam em suas pretensões, mas afirmaram a soberania argentina na Patagônia e a chilena no Estreito de Magalhães. Dessa forma, o tratado funcionou como uma maneira de neutralizar os desentendimentos a respeito das jurisdições de cada país, somados à incerteza quanto aos rumos da diplomacia chilena após a Guerra do Pacífico.

A vitória chilena da Guerra do Pacífico colocou para a Argentina uma necessidade que conter possíveis pretensões expansionistas chilenas em relação ao seu litígio na Patagônia, e os tratados realizados no período tiveram como princípio impedir essa possibilidade de expansão e buscar estabelecer um “equilíbrio de poder” na região. (LACOSTE, 2004, p. 54)

A impossibilidade de resolução do litígio com o tratado de 1881 recolocou a iminência de conflito armado entre os dois países. Tendo como parâmetro duas posições ambíguas, esse tratado incitou outras divergências interpretativas entre as comissões de limites dos dois países. O conhecimento de novos territórios agregava elementos para a disputa, levando à criação de novas bases diplomáticas, como o protocolo de 1893. Contendo disposições adicionais ao tratado de 1881, tentavam-se esclarecer os dispositivos contraditórios acrescentando o princípio do "encadeamento principal dos Andes" como forma de precisar quais seriam os "altos picos" citados. Do mesmo modo,

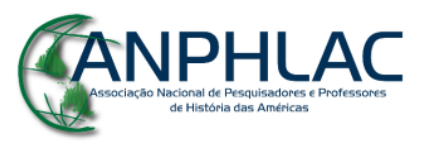

Revista Eletrônica da ANPHLAC, ISSN 1679-1061, №. 22, p. 86-117, Jan./Jun., 2017.

http://revista.anphlac.org.br 
incluíam-se na demarcação os territórios insulares, como as ilhas ao sul da Terra do Fogo. Além de considerar a linha divisória nos Andes, o protocolo ratificava as áreas banhadas pelo Pacífico como parte da jurisdição chilena, restringindo a possibilidade de pleito argentino, mesmo que alegando o deságue dos rios nesse oceano.

A tentativa de elucidação dos princípios do tratado de 1881 dividiu as comissões de limites. Os peritos e representantes diplomáticos argentinos tendiam a desconsiderar o critério da "divisão de águas" ao interpretar o protocolo de 1893. Segundo essa interpretação, o mesmo era válido para o acordo efetuado em 1896. Nesse último, ao estipular o limite na cordilheira dos Andes, a palavra cordilheira, utilizada no singular, fazia relação ao "encadeamento principal dos Andes" que, no entendimento dos peritos argentinos, representava a adoção da fórmula dos "picos mais altos". Na porção austral da Patagônia, a adoção do divortia aquarum ia de encontro com a consideração dos limites nos Andes, já que a demarcação sairia de seu encadeamento principal. (CISNEROS, 1998, p. 25) Excluía-se, assim, a ideia de fixar uma linha entre os rios que desembocariam em um ou outro oceano e construíam-se parâmetros de áreas de influência dentro dessa busca de "equilíbrio de poder" regional, mantendo a Argentina no Atlântico e o Chile no Pacífico. (LACOSTE, 2004, p. 58)

Foi durante o segundo governo Roca (1898-1904) que os dois países vizinhos cederam à arbitragem como forma de resolver suas querelas nos territórios do sul. As tentativas de resolução das questões por meio de comissões de peritos de ambas as repúblicas se constituíram em um grande impasse. O trabalho efetuado pelas comissões de peritos dos dois países não conseguia chegar a um acordo quanto aos critérios a serem utilizados na definição dos limites, não avançando nas negociações. Entre as desconfianças mútuas e a "paz armada", o trabalho de demarcação ficava restrito à geopolítica contida nos acertos diplomáticos.

Na cidade de Santiago, o perito argentino Francisco Perito Moreno informou o ministro das Relações Exteriores a respeito das reuniões realizadas entre as comissões de limites no começo de 1898. Cada comissão apresentava seus relatórios sobre as áreas a serem demarcadas, formando "subcomissões mistas" com representantes dos dois países a fim de acordar os locais onde se fixariam as linhas de fronteira. Na visão do perito argentino, era provável que os chilenos optassem por encaminhar a questão à arbitragem, pois Barros Arana mantinha suas pretensões no divortia aquarum,

\section{GANPHLAC}

Revista Eletrônica da ANPHLAC, ISSN 1679-1061, №. 22, p. 86-117, Jan./Jun., 2017.

http://revista.anphlac.org.br 
acarretando na falta de consenso pleno entre as comissões. Apesar da sustentação da divergência principal entre elas, as reuniões produziram resultados favoráveis à consolidação da fronteira em alguns pontos da cordilheira.

Mesmo com a pouca eficácia das negociações entre os peritos, foi acordado uma tentativa de consenso entre os governos no tocante às áreas de maior discordância. Em relação à Patagônia, a reunião de agosto pretendia colocar fim às disputas pelas áreas localizadas na porção final da cordilheira, nas proximidades com o Estreito de Magalhães, procurando uma concordância para a utilização dos critérios de demarcação: "si en la parte peninsular del sur, al acercarse al paralelo $52^{\circ}$, se interna ó no la Cordillera de los Andes en los canales del Pacífico que allí existen.” (Amancio Alcorta, ministro das relações exteriores da Argentina, Buenos Aires, 6/07/1898, AGN, Fundo Perito Moreno, leg. 3) Com a persistência dos critérios a serem adotados na demarcação (altos picos ou divisor de águas), os governos encaminhariam as atas dos peritos para o governo britânico atuar como árbitro da disputa.

Os dois peritos, Barros Arana e Francisco P. Moreno, deveriam elaborar a linha a qual julgavam coerentes. A fronteira seria estabelecida nos pontos em comum, enquanto as divergências seriam encaminhadas à arbitragem. Toda a extensão por onde passaria a fronteira foi dividida em três partes a fim de facilitar os estudos e as decisões arbitrais. Seriam elas: trechos do paralelo $23^{\circ}$ ao $26^{\circ}$ (referentes à Puna de Atacama, próximo ao território boliviano), do paralelo $26^{\circ}$ ao $52^{\circ}$ (até o final da cordilheira dos Andes, no sul) e as ilhas próximas ao paralelo $52^{\circ}$. Uma nova ata expunha os pontos divergentes entre os peritos, verificando inúmeros impasses, como a linha que ia desde as proximidades do lago Nahuel Huapi até o lago Viedma, em Santa Cruz. (CISNEROS, 1998, p. 30) No mês de dezembro de 1898, foi solicitada a arbitragem britânica, disposta em ata realizada em setembro, no caso da falta de um acordo.

Entre tensões diplomáticas e crises políticas, a década de 1890 terminava com a perspectiva de apaziguamento entre os dois países, colocando a situação do litígio sob a responsabilidade de uma comissão britânica experiente na demarcação de limites em países europeus. Na ocasião da viagem do presidente Roca à Patagônia, foi promovido um encontro com o presidente chileno, Federico Errazurríz. Como parte das políticas diplomáticas emanadas em seu governo, é factível concluir que as pretensões de Roca, tanto em sua passagem pela Patagônia quanto no encontro com o presidente, fossem as

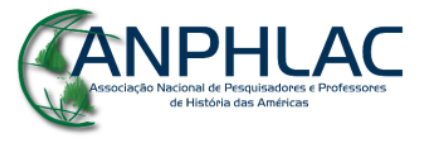

Revista Eletrônica da ANPHLAC, ISSN 1679-1061, №. 22, p. 86-117, Jan./Jun., 2017.

http://revista.anphlac.org.br 
de assegurar a jurisdição argentina sobre as terras patagônicas, ao mesmo tempo em que promovia uma maior aproximação com o governo chileno. Nessa ocasião, ambos os presidentes demonstraram consentimento na realização da arbitragem britânica a fim de diminuir tensão ocasionada. (CISNEROS, 1998, p. 48) Atitude condizente com o pensamento de setores da política argentina vinculados à agroexportação, aos quais não interessava a continuidade das disputas territoriais, pois estas poderiam resultar em um conflito bélico, prejudicando as exportações argentinas. Também se tornava consenso que as áreas em litígio, próximas ao Estreito, não gerariam retorno econômico suficiente para compensar uma atitude bélica. (ROCK, 1989, p. 292)

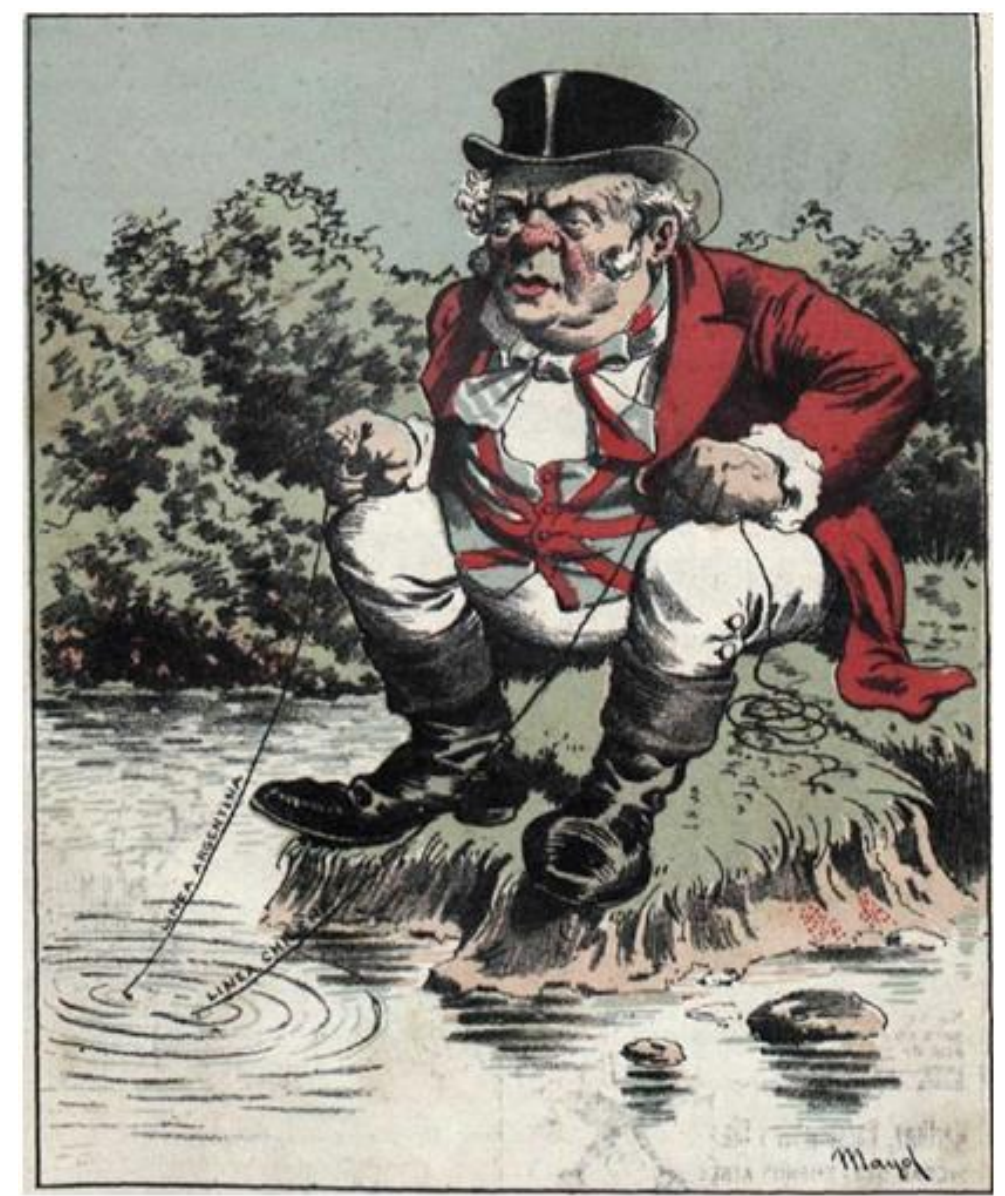

Imagem 1 - Árbitro britânico "pescando" com as linhas de fronteira"

\footnotetext{
${ }^{9}$ Revista Caras y Caretas, 1 a edição, 1/08/1898. Disponível em: http://hemerotecadigital.bne.es/datos1 /numeros/internet/Argentina/Caras\%20y\%20caretas\%20(Buenos\%20Aires)/1898/189810/18981008/1898 1008_00001.pdf\#page=1 Acesso em: 25 de julho de 2015. Legenda da imagem: Aunque las líneas ha echado, enredadas en el fondo, no ha que quedar sin pescado, porque es hombre acostumbrado á pescar por lo más hondo.
}

\section{GANPHLAC}

Revista Eletrônica da ANPHLAC, ISSN 1679-1061, №. 22, p. 86-117, Jan./Jun., 2017.

http://revista.anphlac.org.br 
As tentativas de apaziguamento não interferiram na corrida armamentista que seguia em execução pelo governo chileno e argentino. O fim da disputa ocorreu somente nos primeiros anos do século XX, com os resultados do laudo britânico e a assinatura dos Pactos de Maio, em 1902. A mudança do corpo diplomático dos dois governos facilitou a realização de um acordo, pois muitos personagens que tendiam a postergar as diferenças foram substituídos por outros com maiores tendências a cooperação. No pacto assinado por ambos os países, concordou-se em interromper a compra de armamentos e em efetuar a demarcação dos limites de acordo com os estudos dos territórios em disputa e da documentação realizada pelo governo britânico.

\section{Conclusões}

Ainda que o Pampa e a Patagônia fossem descritos como áreas vazias e incógnitas em comparação aos espaços litorâneos, eram habitados por grupos indígenas política e militarmente organizados, capazes de oferecer resistência à implantação do projeto nacional civilizador em suas terras. Sujeitos de sua própria história, os nativos se valeram conscientemente de intercâmbios, alianças e traições, visando frear os impulsos civilizadores do Estado nacional.

Embora as discussões sobre o Deserto austral se tenham feito presentes desde a existência do Vice-Reinado do Rio da Prata, foi a partir de fins da década de 1860 que esse conceito adquiriu maior relevância e notoriedade no espaço público argentino. Diversos projetos de lei foram encaminhados ao Congresso Nacional com o objetivo de estender a transposição da linha de fronteira nacional aos rios Negro e Neuquén, servindo de base para a organização de expedições militares capazes de solucionar definitivamente a questão da supressão das fronteiras internas.

Com a superação dos conflitos políticos internos que assolavam o país e com o término da Guerra do Paraguai, deu-se início a um irremediável processo de expansionismo territorial, elaborado primeiramente pelo Ministro da Guerra e Marinha Adolfo Alsina e, após seu repentino falecimento, reformulado pelo seu crítico Julio Argentino Roca. Através da utilização das novas tecnologias (o telégrafo, os navios a vapor, os fuzis Remington) e do envolvimento da cúpula do Ministério da Guerra e da Marinha e das forças do Exército argentino, tornou-se possível desenvolver táticas de

\section{GANPHLAC}

Revista Eletrônica da ANPHLAC, ISSN 1679-1061, №. 22, p. 86-117, Jan./Jun., 2017.

http://revista.anphlac.org.br 
guerra subjacentes ao processo de expansão territorial e organizar expedições militares destinadas a penetrar em território "inimigo".

Após a conquista do Pampa, o Estado argentino voltou-se para a questão das fronteiras externas e empenhou-se na conquista da Patagônia e na eliminação dos últimos grandes cacicados da região. A presença da autoridade estatal na cordilheira fazia-se necessária diante dos conflitos limítrofes com a República chilena, que havia se fortalecido no cenário internacional após a experiência da Guerra do Pacífico. Foram muitas as tentativas de elaboração de tratados limítrofes, que atenuaram possíveis conflitos bélicos.

\section{Referências Bibliográficas}

Archivo General de la Nación, Argentina: Fundo Julio Argentino Roca / Fundo Perito Moreno

Archivo del Congreso Nacional Argentino: La Tribuna / La Nación / La República

Biblioteca Nacional de Chile: El Mercurio de Valparaiso / El Ferrocarril de Santiago

Biblioteca del Congreso Nacional de Chile: Tratados de Limites

ALBERDI, Juan Bautista. Bases y puntos de partida para la organización política de la República Argentina (1852). Disponível em: www.hacer.org/pdf/bases.pdf Acesso em: 26 de julho de 2015.

BANDIERI, Susana. Historia de la Patagonia. $2^{\mathrm{a}}$ ed. Buenos Aires: Sudamericana, 2009.

BECHIS, Martha A. Piezas de etnohistoria y de antropología histórica. $1^{\mathrm{a}}$ ed. Buenos Aires: Sociedad Argentina de Antropología, 2010.

. La organización nacional y las tribus pampeanas en Argentina durante el siglo XIX. Revista Tefros, vol. 4, n. 2, ago./dic., 2006.

BENGOA, José. Historia del pueblo mapuche. Santiago: Lom Eds, 2000.

CISNEROS, Andrés; ESCUDÉ, Carlos. Historia General de las Relaciones Exteriores de la Republica Argentina. Tomo VI. Parte I. $1^{\mathrm{a}}$ ed. Buenos Aires: Grupo editor Latinoamericano, 1998.

\section{GANPHLAC}

Revista Eletrônica da ANPHLAC, ISSN 1679-1061, №. 22, p. 86-117, Jan./Jun., 2017.

http://revista.anphlac.org.br 
DEL RIO, Walter Mario. Memorias de expropiación (1872-1943). Buenos Aires: Universidad Nacional de Quilmes Editorial, 2005.

DE MARCO, Miguel Ángel. La Guerra de la Frontera: luchas entre indios y blancos (1536-1917). 1 $1^{\text {a }}$ ed. Buenos Aires: Emecé, 2010.

ENCINA, Francisco. Historia de Chile. Tomo XXXI. Santiago: Editorial Ercilla, 1986.

FRASKIN, Raúl; GARAVAGLIA, Juan Carlos. La Argentina Colonial: El Río de la Plata entre los siglos XVI y XIX. Buenos Aires: Siglo Veintiuno, 2009.

JONG, Ingrid. Las Alianzas Políticas indígenas en el período de la Organización Nacional: una visión desde la Política de tratados de Paz (Pampa y Patagonia 18521880). In: QUIJADA, Monica (Ed.). De los cacicazgos a la ciudadania. Sistemas de frontera, Rio de la Plata, siglos XVIII-XX. Berlin: Ibero-Amerikanisches Institut, 2011. LACOSTE, Pablo. Argentina, Chile y sus vecinos. Tomo I. Buenos Aires: Caviar Bleu, 2004.

MASSES, Enrique Hugo. Estado y Cuestión Indígena: El destino final de los indios sometidos en el sur del territorio (1878-1930). Buenos Aires: Prometeo, 2010.

NACUZZI, Lidia; LUCAIOLI, Carina P. Fronteras: Espacios de Interacción en las tierras bajas del sur de América. Buenos Aires: Sociedad Argentina de Antropología, 2010.

OJEDA, Jorge Pavez. Cartas mapuche (siglo XIX). Santiago: CoLibris/Ocho Libros editores, 2008.

OLASCOAGA, Manuel J. Estudio Topográfico de la Pampa e Rio Negro. (1880) Tomo I. Buenos Aires: Comisión Nacional Monumento al Teniente General Roca, 1940.

OSZLAK, Oscar. La formación Del Estado Argentino: orden, progreso y organización nacional. $4^{\mathrm{a}}$ ed. Buenos Aires: Emecé, 2009.

PRATT, Mary Louise. Imperial Eyes: Travel, Writing and Tranculturation. $2^{\mathrm{a}}$ ed. New York: Routledge, 2008.

QUIJADA, Monica (Ed.). De los cacicazgos a la ciudadania. Sistemas de frontera, Rio de la Plata, siglos XVIII-XX. Berlin: Ibero-Amerikanisches Institut, 2011.

ROCK, David. Argentina 1516-1987: Desde la colonización hasta Alfonsín. Buenos Aires: Alianza Editorial, 1989.

RODRIGUES, Julia. Civilizing Argentina: science, medicine and the modern state. University of North Carolina Press: 2006.

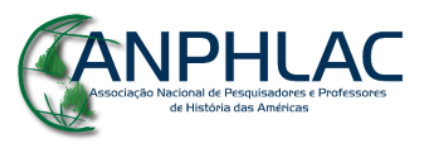

Revista Eletrônica da ANPHLAC, ISSN 1679-1061, №. 22, p. 86-117, Jan./Jun., 2017.

http://revista.anphlac.org.br 
SABATO, Hilda. Historia de la Argentina. 1852-1890. Buenos Aires: Siglo Veintiuno, 2012.

SANTOS, Luís Cláudio Villafañe Gomes. O Império e as Repúblicas do Pacífico. As relações do Brasil com Chile, Bolívia, Peru, Equador e Colômbia (1822-1889). Curitiba: Ed. da UFPR, 2002.

TORRE, Claudia. Estudios Preliminares. In: El otro desierto de la Nación argentina. Antología de la narrativa expedicionaria. Bernal: Universidad Nacional de Quilmes Editorial, 2010.

VEZUB, Julio Esteban. Valentin Saygueque y la Gobernación Indígena de las Manzanas. Poder y etnicidad en la Patagonia septentrional (1860-1881). Buenos Aires, Prometeo, 2009.

VILLALOBOS, Sergio. Historia de Chile. Santiago: Ed. Universitaria, 1996. 